\title{
KISS1R wt Allele
}

National Cancer Institute

\section{Source}

National Cancer Institute. KISS1R wt Allele. NCI Thesaurus. Code C51459.

Human KISS1R wild-type allele is located in the vicinity of $19 q 13.3$ and is approximately 3 $\mathrm{kb}$ in length. This allele, which encodes KiSS-1 receptor protein, is involved in both the regulation of endocrine function and in the onset of puberty. 